\title{
The Effect of Breastfeeding Duration and Parity on the Risk of Epithelial Ovarian Cancer: A Systematic Review and Meta-analysis
}

\author{
Ho Kyung Sung ${ }^{1}$, Seung Hyun Ma ${ }^{1,2}$, Ji-Yeob Choi ${ }^{1,2,3}$, Yunji Hwang ${ }^{1,2,3}$, Choonghyun Ahn ${ }^{1,2,3}$, Byoung-Gie Kim ${ }^{4}$, \\ Yong-Man Kim ${ }^{5}$, Jae Weon Kim ${ }^{6}$, Sokbom Kang ${ }^{7}$ Jaehoon Kim ${ }^{8}$, Tae Jin Kim ${ }^{9}$, Keun-Young Yoo' , Daehee Kang ${ }^{1,2,3}$, \\ Suekyung Park ${ }^{1,2,3}$
}

${ }^{1}$ Department of Preventive Medicine, Seoul National University College of Medicine, Seoul; ${ }^{2}$ Cancer Research Institute, Seoul National University, Seoul; ${ }^{3}$ Department of Biomedical Science, Seoul National University Graduate School, Seoul; ${ }^{4}$ Department of Obstetrics and Gynecology, Samsung Medical Center, Sungkyunkwan University School of Medicine, Seoul; ${ }^{5}$ Department of Obstetrics and Gynecology, Asan Medical Center, University of Ulsan College of Medicine, Seoul; ' Department of Obstetrics and Gynecology, Seoul National University Hospital, Seoul National University College of Medicine, Seoul; ${ }^{7}$ Department of Gynecologic Oncology, National Cancer Center, Goyang; ${ }^{8}$ Division of Gynecologic Oncology, Department of Obstetrics and Gynecology, Gangnam Severance Hospital, Yonsei University College of Medicine, Seoul; ${ }^{9}$ Department of Obstetrics and Gynecology, Cheil General Hospital and Women's Healthcare Center, Kwandong University College of Medicine, Seoul, Korea

Objectives: We conducted a systematic review and meta-analysis to summarize current evidence regarding the association of parity and duration of breastfeeding with the risk of epithelial ovarian cancer (EOC).

Methods: A systematic search of relevant studies published by December 31, 2015 was performed in PubMed and EMBASE. A random-effect model was used to obtain the summary relative risks (RRs) and $95 \%$ confidence intervals (Cls).

Results: Thirty-two studies had parity categories of 1, 2, and $\geq 3$. The summary RRs for EOC were 0.72 ( $95 \% \mathrm{Cl}, 0.65$ to 0.79$), 0.57$ (95\% $\mathrm{Cl}, 0.49$ to 0.65$)$, and $0.46(95 \% \mathrm{Cl}, 0.41$ to 0.52$)$, respectively. Small to moderate heterogeneity was observed for one birth ( $p<0.01$; $\left.\mathrm{Q}=59.46 ; \mathrm{I}^{2}=47.9 \%\right)$. Fifteen studies had breastfeeding categories of $<6$ months, $6-12$ months, and $>13$ months. The summary RRs were $0.79(95 \% \mathrm{Cl}, 0.72$ to 0.87$), 0.72(95 \% \mathrm{Cl}, 0.64$ to 0.81$)$, and $0.67(95 \% \mathrm{Cl}, 0.56$ to 0.79$)$, respectively. Only small heterogeneity was observed for $<6$ months of breastfeeding $\left(p=0.17 ; \mathrm{Q}=18.79, \mathrm{I}^{2}=25.5 \%\right)$. Compared to nulliparous women with no history of breastfeeding, the joint effects of two births and $<6$ months of breastfeeding resulted in a 0.5 -fold reduced risk for EOC.

Conclusions: The first birth and breastfeeding for $<6$ months were associated with significant reductions in EOC risk.

Key words: Ovarian neoplasms, Parity, Breast feeding, Reproduction, Risk factors, Meta-analysis

Received: June 29, 2016 Accepted: September 8, 2016

Corresponding author: Suekyung Park, MD, PhD

103 Daehak-ro, Jongno-gu, Seoul 03080, Korea

Tel: +82-2-740-8338, Fax: +82-2-747-4830

E-mail: suepark@snu.ac.kr

This is an Open Access article distributed under the terms of the Creative Commons Attribution Non-Commercial License (http://creativecommons.org/licenses/bync/4.0// which permits unrestricted non-commercial use, distribution, and reproduction in any medium, provided the original work is properly cited.

\section{INTRODUCTION}

Worldwide, ovarian cancer is the seventh most common cancer in women. Furthermore, it is the sixth leading cause of cancer deaths in women and the second most common cause of death among those with gynecologic cancers [1]. Approximately $90 \%$ of ovarian cancers are of epithelial origin [2], with the remaining $10 \%$ composed of sex cord-stromal tumors $(5 \%$ 
to $8 \%$ ), germ cell tumors ( $3 \%$ to $5 \%$ ), and other rare types of ovarian cancer [3].

Most ovarian cancers are life-threatening and are notorious for having a poor prognosis, as they are usually diagnosed at an advanced stage. Moreover, screening results based on pelvic imaging or tumor markers for early detection remain unsatisfactory [4]. Therefore, to reduce the risk of ovarian cancer, primary prevention, such as avoiding risk factors or strengthening exposure to preventive factors, is important.

Reproductive risk factors for epithelial ovarian cancer (EOC) have been extensively explored in epidemiologic studies. For instance, a pooled analysis of 12 US case-control studies in 1992 showed that parous women and those who had breastfed had a lower risk of EOC $[5,6]$. The protective effect of parity and breastfeeding against EOC is biologically plausible and can be explained by two hypotheses: (1) the incessant ovulation hypothesis, in which monthly ovulation might increase the odds of genetic mutations, potentially leading to subsequent malignant changes [7], and (2) the gonadotropin hypothesis, in which ovarian overstimulation by elevated gonadotropins might trigger hyperproliferation, including subsequent malignant transformation [8]. A pooled analysis in 1992 showed that the greatest protection was associated with the first birth and the first few months of breastfeeding [5]. However, this was only observed in a pooled analysis of six population-based case-control studies, not in hospital-based casecontrol studies.

Since 1992, many studies from around the world have reported associations of parity and breastfeeding with ovarian cancer. However, findings concerning the protective role of increasing parity and duration of breastfeeding remain inconsistent. For parity, some studies have indicated that the first birth reduces ovarian cancer risk more than subsequent births [913]. In contrast, other studies have reported that the second birth was associated with a greater protective effect [14-16]. Likewise, for breastfeeding, some studies have indicated that the first six months of breastfeeding reduce risk more than a month of subsequent breastfeeding $[17,18]$, whereas other studies have reported that each additional six months of breastfeeding confer approximately the same level of additional risk reduction $[12,19]$.

Therefore, we conducted a systematic review and metaanalysis to summarize the current evidence regarding the association of parity and duration of breastfeeding with EOC risk. The aim of this study was to clarify the threshold for risk reduction among the studies without heterogeneity across the results. An additional aim was to perform a meta-analysis to estimate the joint risk reductions associated with parity and breastfeeding.

\section{METHODS}

\section{Search Strategy}

We performed a literature search including studies published through December 2015 using the following search terms in the PubMed and EMBASE databases (1) (parity or "number of live births") and (ovary or ovarian) and (cancer or tumor or neoplasm or malignancy) or (2) (breastfeeding or lactation) and (ovary or ovarian) and (cancer or tumor or neoplasm or malignancy). Furthermore, to find any additional published studies, a manual search was performed by checking all references of prior meta-analyses $[5,6.8,20-23]$ and of all the original studies. This systematic review was planned, conducted, and reported in adherence to the standards of quality for reporting meta-analyses [24,25].

\section{Study Selection}

To be included, studies had to meet the following criteria: (1) the studies were observational (case-control or cohort studies), (2) the exposures of interest were the number of live births and the total duration of breastfeeding, (3) the outcome of interest was EOC, (4) odds ratios (ORs) or relative risk (RR) estimates with $95 \%$ confidence intervals (Cls) were reported or sufficient data were present to allow the calculation of these effect measures, and (5) articles were published in the English language. In the case of overlapping data, the study with the largest number of cases was included. As fertility treatments and BRCA mutation effects on EOC may alter the association between parity/breastfeeding and EOC [26], we excluded studies conducted on specific populations, such as $B R C A-1$ or BRCA-2 mutation carriers or infertile women treated with fertility drugs. The detailed steps of our literature search are shown in Figure 1.

\section{Data Extraction}

Data extraction was conducted independently by two authors. Disagreements were discussed and resolved by consensus. The following data were collected from each study: the first author's last name, publication year, study region and design, study period, participant age, sample size (cases and 


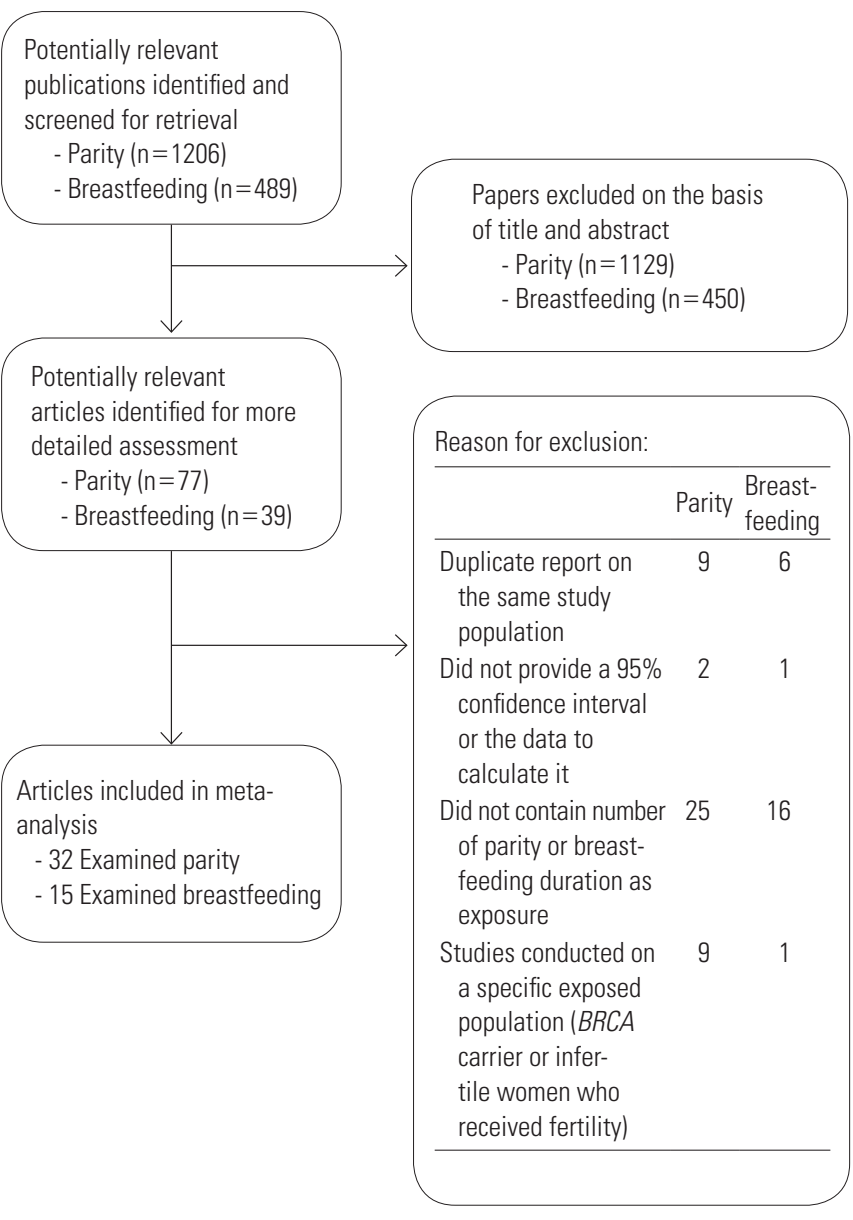

Figure 1. Literature search algorithm.

controls or cohort size), exposure variables (parity or total breastfeeding duration), study-specific adjusted RR or OR with 95\% Cls for each exposure category, and factors matched or adjusted for in the design or data analysis. If no adjusted RR or OR was presented, we included crude estimates. If no RRs or ORs were presented in a given study, we calculated them and the $95 \% \mathrm{Cls}$ according to the raw frequencies presented in the article. The quality of the study was assessed independently by two authors using the 9-star Newcastle-Ottawa Scale (range, 0 to 9 stars) [27]. This measure assesses aspects of methodology in observational studies related to study quality, including the selection of cases, comparability of populations, and ascertainment of exposure to risks.

\section{Statistical Analysis}

The study-specific RRs or ORs with $95 \%$ Cls were used to determine the principal outcome. Because the OR closely approximates the RR for rare diseases, the RR can be estimated from a case-control study using the $\mathrm{OR}$ as an approximation [28]. Ovarian cancer is relatively rare and its absolute risk is low, with an incidence of 6.1 per 100000 women [1]. Therefore, in the meta-analysis, ORs from case-control studies were used as an equivalent of RRs from cohort studies; we reported all results as RRs [22.29]. Mantel-Haenszel crude estimates of the RRs and corresponding 95\% Cls were calculated when the RRs were not present but enough data were available. Logit RR estimates were calculated when the data were sparse. A random-effect model was used to obtain the summary RR and $95 \% \mathrm{Cl}$. To assess whether the risk of EOC decreased with increasing parity or duration of breastfeeding, we categorized parity $(1,2$, or $\geq 3 ; 1,2,3$, or $\geq 4$; and $1,2,3,4$, or $\geq 5)$ relative to nulliparity and total breastfeeding duration ( $<6$ months, 6-12 months, or $\geq 13$ months; and $<6$ months, 6-12 months, 13-24 months, or $\geq 25$ months) relative to never having breastfed, as reported by most of the studies.

One study did not provide the required risk estimates for analysis or separate the risk estimates for different categories of parity or breastfeeding duration. For this study, we used the method proposed by Fleiss and Gross [30]. This method allows adjusted effect estimates and Cls to be calculated for any alternative comparison of levels and can help in a dose-response meta-analysis. Briefly, we combined risk estimates obtained through a simple fixed-effects meta-analysis wherein the subjects were divided into unexposed groups $(i=0)$ and exposed groups $(i=1, \ldots, \mathrm{n})$, and estimates $(R i)$ with lower and upper $95 \%$ Cls were available. To obtain the $R_{1+}$, we meta-analyzed $R_{1}, R_{2}, R_{3}, \ldots, R_{n}$ using a fixed-effect model. The categories of parity or breastfeeding duration varied across studies; accordingly, the number of studies included in each metaanalysis and the summary RRs in each meta-analysis were different depending upon the number of categories.

Statistical heterogeneity among studies was evaluated with the Cochran $Q$ and I-squared statistics [31]. The significance level for the $Q$ statistic was defined as $p$-value $<0.1$. The Isquared value represents the proportion of total variation composed of between-study variation [31]. I-squared values $\leq 25 \%, 25.1-50 \%, 50.1-75 \%$, and $>75 \%$ were interpreted as indicating no, small, moderate, and significant heterogeneity, respectively [32]. Subgroup analyses were conducted to explore the potential sources of heterogeneity, according to the following characteristics: (1) study design (cohort, case-control studies); (2) the quality of study methodology across studies, with studies with $\geq 8$ stars considered high-quality and those 
with $\leq 7$ stars considered low-quality as per the 9-star Newcastle-Ottawa Scale; and (3) year of publication $(<2000, \geq$ 2000), respectively.

Publication bias was evaluated using the Begg rank correlation and the Egger linear regression test, in which p-vlaue $<0.05$ were considered representative of statistically significant publication bias [33].

From the meta-analyzed result, to calculate the RR for the joint effect of parity and breastfeeding, we applied the log-linear dose-response model proposed by Berlin et al. [34].

We configured the following formula for the multivariate linear logit regression of two factors:

$$
\text { Logit } P=a+\beta_{1} \chi_{1}+\beta_{2} \chi_{2} ;
$$

where $P$ is the probability of a particular outcome (EOC risk), $a$ is the intercept from the linear regression equation, $\beta$ is the regression coefficient multiplied by some value of the predictor, and $\chi$ is the risk factor (parity and breastfeeding).

Using this equation yields the value of the RR for the joint effects of parity and breastfeeding duration. For example, in the case of a subject who has no risk factors, logit $(P)$ is $a$. In this case, the probability of EOC is $\exp (a)=1.0$. In the case of a subject with only $\chi_{1}$, logit $(P)$ is $a+\beta_{1}$. In the case of a subject with both $\chi_{1}$ and $\chi_{2}$, logit $(P)$ is $a+\beta_{1}+\beta_{2}$. Accordingly, the probability of $E O C$ is $\exp \left(\beta_{1}+\beta_{2}\right)=O R_{1} \times O R_{2}$.

Since the category of parity and breastfeeding duration varied across studies, to calculate the RR for the joint effect of parity and breastfeeding, we used the summary RR for parity and breastfeeding duration that contained the largest number of studies.

All statistical analyses were performed with Stata version 12.0 (StataCorp., College Station, TX, USA).

\section{RESULTS}

\section{Study Characteristics}

The characteristics of the 32 studies included with data regarding parity and the 15 studies included with data regarding breastfeeding are shown in Supplemental Tables 1 and 2. For parity, six cohort studies and 26 case-control studies were included. The included studies were conducted between 1973 and 2008. Of the 32 studies, 14 were performed in North America, 12 in Europe, four in Asia, one in Australia, and one in

Table 1. Summary risk estimates for the association of epithelial ovarian cancer with parity and breastfeeding duration

\begin{tabular}{|c|c|c|c|c|c|c|}
\hline & & No. of studies ${ }^{1}$ & $\begin{array}{c}\text { Summary RR } \\
(95 \% \mathrm{CI})^{2}\end{array}$ & $p$-heterogeneity & 0-statistic & I-squared (\%) \\
\hline \multirow[t]{12}{*}{ Parity (n) } & 1 & 32 & $0.72(0.65,0.79)$ & $<0.01$ & 59.46 & 47.9 \\
\hline & 2 & & $0.57(0.49,0.65)$ & $<0.01$ & 175.09 & 82.3 \\
\hline & $\geq 3$ & & $0.46(0.41,0.52)$ & $<0.01$ & 186.20 & 81.7 \\
\hline & 1 & 21 & $0.70(0.62,0.80)$ & $<0.01$ & 52.97 & 56.6 \\
\hline & 2 & & $0.53(0.45,0.62)$ & $<0.01$ & 146.32 & 84.3 \\
\hline & 3 & & $0.48(0.42,0.54)$ & $<0.01$ & 69.26 & 66.8 \\
\hline & $\geq 4$ & & $0.39(0.36,0.42)$ & $<0.01$ & 80.00 & 71.3 \\
\hline & 1 & 12 & $0.68(0.58,0.81)$ & $<0.01$ & 35.60 & 66.3 \\
\hline & 2 & & $0.50(0.41,0.61)$ & $<0.01$ & 94.17 & 87.3 \\
\hline & 3 & & $0.43(0.40,0.46)$ & $<0.01$ & 47.20 & 74.6 \\
\hline & 4 & & $0.34(0.29,0.41)$ & 0.01 & 27.19 & 55.9 \\
\hline & $\geq 5$ & & $0.33(0.29,0.37)$ & 0.01 & 26.72 & 55.1 \\
\hline \multirow[t]{7}{*}{ Breastfeeding duration (mo) } & $<6$ & 15 & $0.79(0.72,0.87)$ & 0.17 & 18.79 & 25.5 \\
\hline & $6-12$ & & $0.72(0.64,0.81)$ & 0.24 & 17.41 & 19.6 \\
\hline & $\geq 13$ & & $0.67(0.56,0.79)$ & $<0.01$ & 39.30 & 64.4 \\
\hline & $<6$ & 6 & $0.87(0.72,1.04)$ & 0.16 & 7.91 & 36.8 \\
\hline & $6-12$ & & $0.71(0.58,0.87)$ & 0.30 & 6.05 & 17.3 \\
\hline & $13-24$ & & $0.75(0.60,0.93)$ & 0.28 & 6.34 & 21.1 \\
\hline & $\geq 25$ & & $0.53(0.36,0.77)$ & $<0.01$ & 21.16 & 73.4 \\
\hline
\end{tabular}

$\mathrm{RR}$, relative risk; $\mathrm{Cl}$, confidence interval.

${ }^{1}$ No publication bias in each category ( $p>0.05$ in both the Begg and Egger tests).

${ }^{2}$ The summary RRs $(95 \% \mathrm{Cls})$ in each meta-analysis were estimated using a random effect model. 
Africa. For breastfeeding, two cohort studies and 13 case-control studies were included. The included studies were conducted between 1978 and 2008. Of the 15 studies, seven were performed in North America, six in Europe, one in Asia, and one in Australia.

\section{Parity and Epithelial Ovarian Cancer Risk}

Thirty-two studies had parity categories of 1,2 , and $\geq 3$. The summary RRs for the first, second, and third births were 0.72 (95\% Cl, 0.65 to 0.79$), 0.57(95 \% \mathrm{Cl}, 0.49$ to 0.65$)$, and 0.46 (95\% $\mathrm{Cl}, 0.41$ to 0.52 ), respectively (Table 1 ). Small to moderate heterogeneity was observed for the first birth $(p<0.01 ; Q=59.46$, $\left.1^{2}=47.9 \%\right)$, whereas significant heterogeneity was observed for the second $\left(p<0.01 ; Q=175.09 ;\left.\right|^{2}=82.3 \%\right)$ and third $(p<0.01$; $\left.Q=186.20 ; I^{2}=81.7 \%\right)$ births. Analyses gave no indication of publication bias. Similar results were also observed for parity categories of $1,2,3$, and $\geq 4$ and $1,2,3,4$, and $\geq 5$.

\section{Duration of Breastfeeding and Epithelial Ovarian Cancer Risk}

Fifteen studies had breastfeeding categories of $<6$ months, 6-12 months, and $\geq 13$ months. The summary RRs for these categories were $0.79(95 \% \mathrm{Cl}, 0.72$ to 0.87$), 0.72(95 \% \mathrm{Cl}, 0.64$ to 0.81$)$ and $0.67(95 \% \mathrm{Cl}, 0.56$ to 0.79$)$, respectively (Table 1$)$. Small or no heterogeneity was observed for $<6$ months ( $p=$ $\left.0.17 ; \mathrm{Q}=18.79 ;\left.\right|^{2}=25.5 \%\right)$ and $6-12$ months $(p=0.24 ; \mathrm{Q}=17.41$; $\left.I^{2}=19.6 \%\right)$, whereas moderate heterogeneity was observed for $\geq 13$ months $\left(p<0.01 ; Q=39.30 ; 1^{2}=64.4 \%\right)$. Analyses gave no indication of publication bias. Similar results were also observed for the breastfeeding categories of $<6$ months, 6-12 months, $13-24$ months, and $\geq 25$ months.

\section{Subgroup Analysis According to Study Design, Study Quality, and Publication Year}

The results from the subgroup analysis according to study design, study quality, and publication year are shown in Table 2. In high-quality studies, the summary RRs for the first, second, and third births were $0.73(95 \% \mathrm{Cl}, 0.64$ to 0.84$), 0.60$ ( $95 \% \mathrm{Cl}, 0.49$ to 0.74$)$, and $0.46(95 \% \mathrm{Cl}, 0.41$ to 0.52$)$, respectively. The summary RRs for $<6$ months, $6-12$ months, and $\geq$ 13 months of breastfeeding were $0.79(95 \% \mathrm{Cl}, 0.68$ to 0.91$)$, $0.82(95 \% \mathrm{Cl}, 0.69$ to 0.97$)$, and $0.79(95 \% \mathrm{Cl}, 0.66$ to 0.95$)$, respectively. The summary RRs of the first birth and $<6$ months of breastfeeding from the analysis of high-quality studies were almost identical to the values from the analysis of all 32 and
15 studies, without heterogeneity $\left(l^{2}=0 \%\right)$.

The summary RR for the first birth in cohort studies was weaker, and only had a borderline significant effect on EOC risk ( $\mathrm{RR}, 0.86 ; 95 \% \mathrm{Cl}, 0.75$ to 1.00 ) relative to case-control studies (RR, $0.69 ; 95 \% \mathrm{Cl}, 0.61$ to 0.77$)$. In contrast, with regards to breastfeeding, the summary RRs for $<6$ months were similar between cohort studies and case-control studies (Table 2), with small heterogeneity.

\section{Relative Risk for the Joint Effect of Parity and Breastfeeding}

The RR for the joint effect of parity and breastfeeding, obtained using the summary RR from the analysis of 32 studies with parity categories of 1,2 , and $\geq 3$ and 15 studies with breastfeeding categories of $<6$ months, $6-12$ months, and $\geq$ 13 months, is shown in Table 3. Compared to nulliparous women who never breastfed, uniparous women with no history of breastfeeding had a nearly $30 \%$ reduced risk for EOC (Table 3). Without breastfeeding, two births and three or more births elicited $40 \%$ and $50 \%$ reduced risks for EOC, respectively. When breastfeeding $<6$ months was added to each parity category, an additional $10 \%$ reduction in EOC risk was found.

\section{DISCUSSION}

The findings of this meta-analysis indicate that parity and breastfeeding experiences in women can help prevent EOC, which is typically life-threatening and has a poor prognosis. In particular, the first birth and the first six months of breastfeeding had a greater protective effect than did subsequent births and/or additional breastfeeding, although multiparity and additional breastfeeding did provide some additional protection. The risk reduction effect of the first birth on EOC risk was almost 30\%, and the combined effect of the first birth and $<6$ months of breastfeeding was $40 \%$; thus, breastfeeding provided a nearly $10 \%$ greater risk reduction. In regards to parity, the EOC risk reduction was highest for the first birth, with some additional protection from the second birth. However, slightly less risk reduction was observed for the third birth (Figure 2). Although a prior meta-analysis suggested a continuous risk reduction of approximately $14 \%$ for each additional pregnancy after the first [5], the current findings show different results, with a gradually decreasing risk from additional parity and/or breastfeeding duration that eventually plateaus (Table 1).

Pregnancy and breastfeeding are thought to reduce EOC risk 
Table 2. Subgroup analysis according to study design, study quality, and publication year

\begin{tabular}{|c|c|c|c|c|c|c|c|c|}
\hline & & & & $\begin{array}{c}\text { No. of } \\
\text { studies }^{1}\end{array}$ & $\begin{array}{c}\text { Summary RR } \\
(95 \% \mathrm{Cl})^{2}\end{array}$ & $\begin{array}{c}p- \\
\text { heterogeneity }\end{array}$ & 0-statistic & I-squared (\%) \\
\hline \multirow[t]{18}{*}{ Parity (n) } & \multirow[t]{6}{*}{ Quality } & \multirow[t]{3}{*}{$\mathrm{High}^{3}$} & 1 & \multirow[t]{3}{*}{8} & $0.73(0.64,0.84)$ & 0.71 & 4.61 & 0.0 \\
\hline & & & 2 & & $0.60(0.49,0.74)$ & 0.03 & 15.86 & 62.2 \\
\hline & & & $\geq 3$ & & $0.46(0.41,0.52)$ & $<0.01$ & 28.06 & 75.1 \\
\hline & & \multirow[t]{3}{*}{ Low $^{4}$} & 1 & \multirow[t]{3}{*}{24} & $0.71(0.63,0.81)$ & $<0.01$ & 54.69 & 57.9 \\
\hline & & & 2 & & $0.56(0.47,0.66)$ & $<0.01$ & 155.48 & 85.2 \\
\hline & & & $\geq 3$ & & $0.46(0.40,0.53)$ & $<0.01$ & 145.47 & 84.2 \\
\hline & \multirow[t]{6}{*}{ Study design } & \multirow[t]{3}{*}{ Cohort } & 1 & \multirow[t]{3}{*}{6} & $0.86(0.75,1.00)$ & 0.77 & 2.54 & 0.0 \\
\hline & & & 2 & & $0.75(0.66,0.84)$ & 0.88 & 1.79 & 0.0 \\
\hline & & & $\geq 3$ & & $0.60(0.54,0.68)$ & 0.34 & 5.63 & 11.1 \\
\hline & & \multirow[t]{3}{*}{ Case-control } & 1 & \multirow[t]{3}{*}{26} & $0.69(0.61,0.77)$ & $<0.01$ & 52.56 & 52.4 \\
\hline & & & 2 & & $0.75(0.66,0.84)$ & $<0.01$ & 147.39 & 83.0 \\
\hline & & & $\geq 3$ & & $0.43(0.38,0.49)$ & $<0.01$ & 132.57 & 81.1 \\
\hline & \multirow[t]{6}{*}{ Year of publication } & \multirow[t]{3}{*}{$<2000$} & 1 & \multirow[t]{3}{*}{24} & $0.68(0.60,0.76)$ & 0.01 & 40.29 & 42.9 \\
\hline & & & 2 & & $0.54(0.45,0.64)$ & $<0.01$ & 144.90 & 84.1 \\
\hline & & & $\geq 3$ & & $0.45(0.39,0.52)$ & $<0.01$ & 136.78 & 83.2 \\
\hline & & \multirow[t]{3}{*}{$\geq 2000$} & 1 & \multirow[t]{3}{*}{8} & $0.84(0.72,0.98)$ & 0.17 & 10.35 & 32.4 \\
\hline & & & 2 & & $0.64(0.54,0.76)$ & 0.03 & 15.45 & 54.7 \\
\hline & & & $\geq 3$ & & $0.49(0.40,0.61)$ & $<0.01$ & 34.34 & 79.6 \\
\hline \multirow{18}{*}{$\begin{array}{l}\text { Breastfeeding } \\
\text { duration (mo) }\end{array}$} & \multirow[t]{6}{*}{ Quality } & \multirow[t]{3}{*}{$\mathrm{High}^{3}$} & $<6$ & \multirow[t]{3}{*}{4} & $0.79(0.68,0.91)$ & 0.43 & 2.76 & 0.0 \\
\hline & & & $6-12$ & & $0.82(0.69,0.97)$ & 0.39 & 2.99 & 0.0 \\
\hline & & & $\geq 13$ & & $0.79(0.66,0.95)$ & 0.33 & 39.30 & 13.0 \\
\hline & & \multirow[t]{3}{*}{ Low $^{4}$} & $<6$ & \multirow[t]{3}{*}{11} & $0.78(0.68,0.90)$ & 0.06 & 17.65 & 43.3 \\
\hline & & & $6-12$ & & $0.69(0.60,0.79)$ & 0.31 & 11.69 & 14.5 \\
\hline & & & $\geq 13$ & & $0.63(0.52,0.78)$ & $<0.01$ & 28.38 & 64.8 \\
\hline & \multirow[t]{6}{*}{ Study design } & \multirow[t]{3}{*}{ Cohort } & $<6$ & \multirow[t]{3}{*}{2} & $0.77(0.63,0.93)$ & 0.22 & 1.53 & 34.6 \\
\hline & & & $6-12$ & & $0.87(0.71,1.06)$ & 0.43 & 0.63 & 0.0 \\
\hline & & & $\geq 13$ & & $0.81(0.67,0.98)$ & 0.33 & 0.97 & 0.0 \\
\hline & & \multirow[t]{3}{*}{ Case-control } & $<6$ & 13 & $0.79(0.70,0.90)$ & 0.09 & 18.97 & 36.8 \\
\hline & & & $6-12$ & & $0.69(0.61,0.77)$ & 0.39 & 12.69 & 8.8 \\
\hline & & & $\geq 13$ & & $0.64(0.53,0.77)$ & $<0.01$ & 31.53 & 61.9 \\
\hline & Year of publication & $<2000$ & $<6$ & 11 & $0.78(0.70,0.86)$ & 0.28 & 12.11 & 17.4 \\
\hline & & & $6-12$ & & $0.70(0.61,0.82)$ & 0.12 & 15.26 & 34.5 \\
\hline & & & $\geq 13$ & & $0.63(0.53,0.76)$ & $<0.01$ & 25.58 & 60.9 \\
\hline & & $\geq 2000$ & $<6$ & 4 & $0.80(0.57,1.12)$ & 0.04 & 8.39 & 64.2 \\
\hline & & & $6-12$ & & $0.75(0.60,0.94)$ & 0.56 & 2.04 & 0.0 \\
\hline & & & $\geq 13$ & & $0.81(0.51,1.27)$ & 0.01 & 11.77 & 74.5 \\
\hline
\end{tabular}

$\mathrm{RR}$, relative risk; $\mathrm{Cl}$, confidence interval.

${ }^{1}$ No publication bias in each category ( $p>0.05$ in both the Begg and Egger test).

${ }^{2}$ The summary RRs (95\% Cls) in each meta-analysis were estimated using a random effect model.

${ }^{3}$ Studies with $\geq 8$ stars were considered high-quality as per the 9-star Newcastle-Ottawa Scale.

${ }^{4}$ Studies with $\leq 7$ stars were considered low-quality as per the 9-star Newcastle-Ottawa Scale.

by decreasing pituitary gonadotropin levels and inducing anovulation [7,35]. Pregnancy and breastfeeding are expected to decrease the likelihood of spontaneous genetic mutation under the incessant ovulation hypothesis and of the hyperprolif- eration of inclusion cysts under the gonadotropin hypothesis. However, the observation that multiparity and additional breastfeeding did not provide an equal amount of protection does not provide evidence for either of these hypotheses. Nev- 
Table 3. Relative risks (RRs) for the joint effect of parity and breastfeeding

\begin{tabular}{|c|c|c|c|c|c|c|}
\hline \multicolumn{2}{|l|}{ Parity (n) } & \multicolumn{5}{|c|}{ Breastfeeding (mo) } \\
\hline Category & $\mathbf{R R}^{1,2}$ & & 0 & $<6$ & $6-12$ & $\geq 13$ \\
\hline & & $\mathrm{RR}^{1,2}$ & 1.00 & 0.79 & 0.72 & 0.67 \\
\hline 0 & 1.00 & Joint RR & 1.0 & & & \\
\hline 1 & 0.72 & & 0.7 & 0.6 & 0.5 & 0.5 \\
\hline 2 & 0.57 & & 0.6 & 0.5 & 0.4 & 0.4 \\
\hline$\geq 3$ & 0.46 & & 0.5 & 0.4 & 0.3 & 0.3 \\
\hline
\end{tabular}

${ }^{1}$ The RRs in each category were estimated using a random effect model.

${ }^{2}$ We used the summary RR from the analysis of 32 studies with parity categories of 1,2, and $\geq 3$ and 15 studies with breastfeeding categories of $<6,6-12$, and $\geq 13$ months (as shown in Table 1).
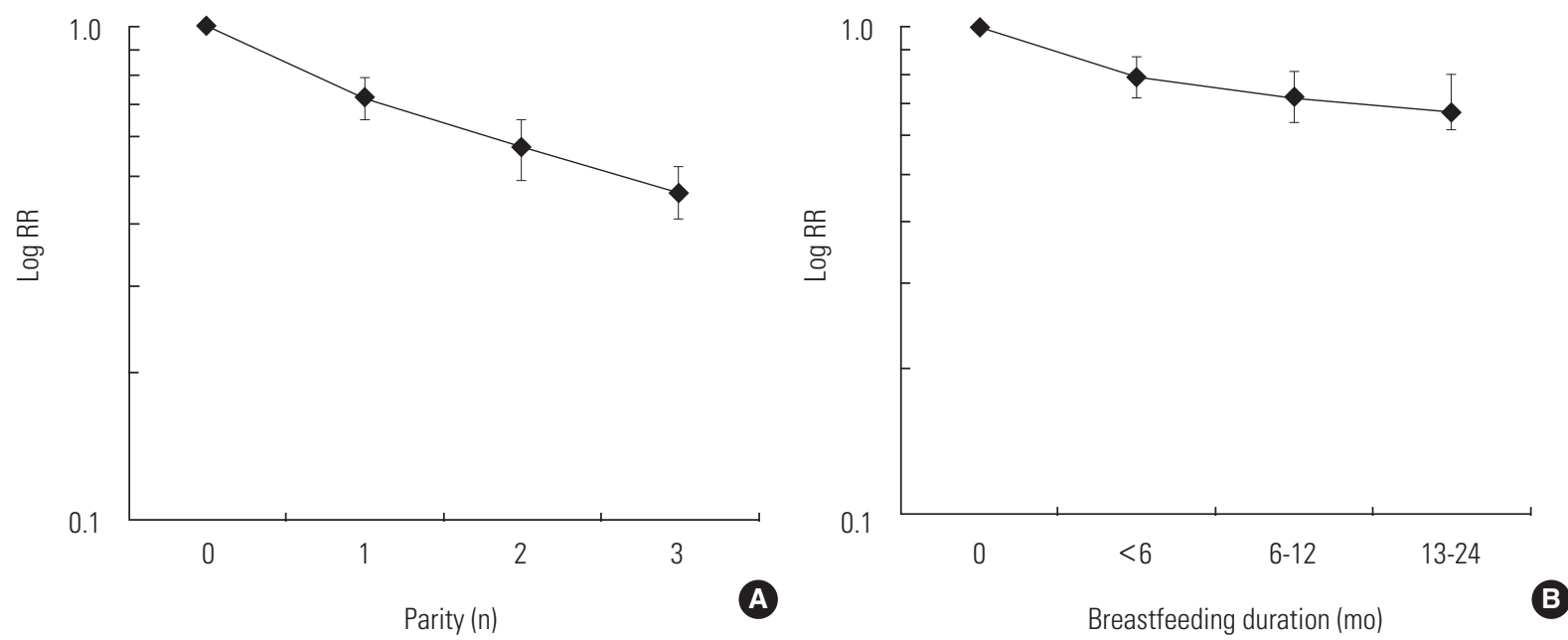

Figure 2. Decreasing epithelial ovarian cancer (EOC) risk with increasing parity and breastfeeding duration. (A) Decreasing EOC risk with increasing parity ${ }^{1,2}$. (B) Decreasing EOC risk with increasing breastfeeding duration ${ }^{1,2}$. $^{1}$ The relative risks (RRs) in each category were estimated using a random effect model. ${ }^{2}$ We used summary RRs from 32 studies for parity and 15 studies for breastfeeding (shown in Table 1).

ertheless, the results of two experimental studies provide biological evidence for the relatively weaker protective effect of additional parity and breastfeeding [36,37]. For instance, high progesterone levels during pregnancy can increase apoptosis, which may clear transformed cells from the ovarian epithelium, meaning that all the accumulated transformed cells are washed fully out by the first pregnancy. Therefore, the first pregnancy provides a stronger protective effect than subsequent pregnancies [36]. In regards to breastfeeding, breastfeeding in the first few months completely inhibits the pulsatile secretion of gonadotropin-releasing hormone and luteinizing hormone, leading to suppression of ovulation [37]. After a couple of months, ovulatory activity may return, even though breastfeeding continues [37]; thus, a longer duration of breastfeeding does not provide an additional protective effect.

Our finding of decreased EOC risk with longer breastfeeding is similar to that reported by prior meta-analyses in 2013 and $2014[22,23]$, but differs from that of a meta-analysis of nine case-control studies conducted in developed countries in 2001, in which breastfeeding for $\geq 12$ months was associated with a significant 0.72 -fold reduced risk of EOC compared to never having breastfed, while breastfeeding $<12$ months did not show such an association ( $\mathrm{OR}, 0.95 ; 95 \% \mathrm{Cl}, 0.80$ to 1.12) [21].

Based on the RR for the joint effect of parity and breastfeeding, women who had two births and breastfed for $<6$ months had a 0.5 -fold reduced risk of EOC. Our findings may provide evidence for developing guidelines for EOC prevention.

The strength of this meta-analysis is that it included all available studies, and the large number of EOC cases allowed for the investigation of the risk associated with different categories of parity and breastfeeding duration. However, the current study also has several limitations. First, our meta-analysis was 
restricted to studies published in indexed journals and might not have included unpublished studies. Second, some residual confounders may not have been excluded and may have influenced the protective effect of parity and breastfeeding, although a large number of potential confounding factors, such as age, race, and use of oral contraceptives, were adjusted for in most of the included studies. Third, significant heterogeneity must be considered. Significant heterogeneity was present in the analysis assessing whether the risk of EOC decreased with increasing parity or duration of breastfeeding, especially for higher parity and longer duration of breastfeeding. Despite the subgroup analyses, heterogeneity still existed in the results of the highest category of parity and longest duration of breastfeeding. Categories of parity and duration of breastfeeding, especially the highest parity and longest duration of breastfeeding, differed among studies and may have contributed to the heterogeneity in the results. However, the first birth and $<6$ months of breastfeeding showed little heterogeneity, and similar results were found in the subgroup analysis to those of the high-quality studies. Fourth, as a meta-analysis of observational studies, the data were prone to biases such as recall and selection bias inherent in the original studies. Cohort studies are less susceptible to bias than case-control studies because information is collected before the diagnosis of the disease. However, only a small number of cohort studies have been published; therefore, it was not possible to analyze the various categories of parity and breastfeeding duration using cohort studies alone. Fifth, the included studies were primarily from North America and Europe. Therefore, the findings may not apply to Asian populations with a low incidence of ovarian cancer.

\section{CONCLUSION}

In conclusion, our findings indicated that the first birth and breastfeeding for $<6$ months were associated with significant reductions in EOC risk. As a modifiable reproductive risk factor, two childbirths and additional breastfeeding, regardless of breastfeeding duration, can reduce EOC risk by $50 \%$. These findings may help to generate recommendations for the prevention of EOC.

\section{ACKNOWLEDGEMENTS}

This work was supported by a grant from the National R\&D Program for Cancer Control, Ministry for Health, Welfare and
Family Affairs, Republic of Korea (0920010).

\section{CONFLICT OF INTEREST}

The authors have no conflicts of interest associated with the material presented in this paper.

\section{ORCID}

Ho Kyung Sung http://orcid.org/0000-0002-1207-0298

Suekyung Park http://orcid.org/0000-0001-5002-9707

\section{REFERENCES}

1. International Agency for Research on Cancer. GLOBOCAN 2012: estimated cancer incidence, mortality and prevalence worldwide in 2012 [cited 2016 Nov 20]. Available from: http:// globocan.iarc.fr/Default.aspx.

2. Prat J; FIGO Committee on Gynecologic Oncology. FIGO's staging classification for cancer of the ovary, fallopian tube, and peritoneum: abridged republication. J Gynecol Oncol 2015;26(2):87-89.

3. Colombo N, Peiretti M, Castiglione M; ESMO Guidelines Working Group. Non-epithelial ovarian cancer: ESMO clinical recommendations for diagnosis, treatment and follow-up. Ann Oncol 2009;20 Suppl 4:24-26.

4. Clarke-Pearson DL. Clinical practice. Screening for ovarian cancer. N Engl J Med 2009;361(2):170-177.

5. Whittemore AS, Harris R, Itnyre J. Characteristics relating to ovarian cancer risk: collaborative analysis of 12 US case-control studies. II. Invasive epithelial ovarian cancers in white women. Collaborative Ovarian Cancer Group. Am J Epidemiol 1992;136(10):1184-1203.

6. Harris R, Whittemore AS, Itnyre J. Characteristics relating to ovarian cancer risk: collaborative analysis of 12 US case-control studies. III. Epithelial tumors of low malignant potential in white women. Collaborative Ovarian Cancer Group. Am J Epidemiol 1992;136(10):1204-1211.

7. Fathalla MF. Incessant ovulation--a factor in ovarian neoplasia? Lancet 1971;2(7716):163.

8. Whittemore AS, Harris R, Itnyre J. Characteristics relating to ovarian cancer risk: collaborative analysis of 12 US case-control studies. IV. The pathogenesis of epithelial ovarian cancer. Collaborative Ovarian Cancer Group. Am J Epidemiol 1992; 136(10):1212-1220. 
9. Risch HA, Marrett LD, Howe GR. Parity, contraception, infertility, and the risk of epithelial ovarian cancer. Am J Epidemiol 1994;140(7):585-597.

10. Ness RB, Grisso JA, Klapper J, Schlesselman JJ, Silberzweig S, Vergona $R$, et al. Risk of ovarian cancer in relation to estrogen and progestin dose and use characteristics of oral contraceptives. Am J Epidemiol 2000;152(3):233-241.

11. Titus-Ernstoff L, Perez K, Cramer DW, Harlow BL, Baron JA, Greenberg ER. Menstrual and reproductive factors in relation to ovarian cancer risk. Br J Cancer 2001;84(5):714-721.

12. Riman T, Dickman PW, Nilsson S, Correia N, Nordlinder H, Magnusson CM, et al. Risk factors for epithelial borderline ovarian tumors: results of a Swedish case-control study. Gynecol Oncol 2001;83(3):575-585.

13. Riman T, Dickman PW, Nilsson S, Correia N, Nordlinder H, Magnusson $\mathrm{CM}$, et al. Risk factors for invasive epithelial ovarian cancer: results from a Swedish case-control study. Am J Epidemiol 2002;156(4):363-373.

14. Hankinson SE, Colditz GA, Hunter DJ, Willett WC, Stampfer MJ, Rosner B, et al. A prospective study of reproductive factors and risk of epithelial ovarian cancer. Cancer 1995;76(2):284290.

15. Weiderpass E, Sandin S, Inoue M, Shimazu T, Iwasaki M, Sasazuki S, et al. Risk factors for epithelial ovarian cancer in Japan results from the Japan Public Health Center-based Prospective Study cohort. Int J Oncol 2012;40(1):21-30.

16. Yang HP, Trabert B, Murphy MA, Sherman ME, Sampson JN, Brinton $L A$, et al. Ovarian cancer risk factors by histologic subtypes in the NIH-AARP Diet and Health Study. Int J Cancer 2012;131(4):938-948.

17. Gwinn ML, Lee NC, Rhodes PH, Layde PM, Rubin GL. Pregnancy, breast feeding, and oral contraceptives and the risk of epithelial ovarian cancer. J Clin Epidemiol 1990;43(6):559-568.

18. Danforth KN, Tworoger SS, Hecht JL, Rosner BA, Colditz GA, Hankinson SE. Breastfeeding and risk of ovarian cancer in two prospective cohorts. Cancer Causes Control 2007;18(5):517523.

19. Siskind V, Green A, Bain C, Purdie D. Breastfeeding, menopause, and epithelial ovarian cancer. Epidemiology 1997;8(2): 188-191.

20. Whittemore AS, Harris R, Itnyre J, Halpern J. Characteristics relating to ovarian cancer risk: collaborative analysis of 12 US case-control studies. I. Methods. Collaborative Ovarian Cancer Group. Am J Epidemiol 1992;136(10):1175-1183.

21. Ip S, Chung M, Raman G, Trikalinos TA, Lau J. A summary of the Agency for Healthcare Research and Quality's evidence report on breastfeeding in developed countries. Breastfeed Med 2009;4 Suppl 1:S17-S30.

22. Luan NN, Wu QJ, Gong TT, Vogtmann E, Wang YL, Lin B. Breastfeeding and ovarian cancer risk: a meta-analysis of epidemiologic studies. Am J Clin Nutr 2013;98(4):1020-1031.

23. Li DP, Du C, Zhang ZM, Li GX, Yu ZF, Wang X, et al. Breastfeeding and ovarian cancer risk: a systematic review and metaanalysis of 40 epidemiological studies. Asian Pac J Cancer Prev 2014;15(12):4829-4837.

24. Stroup DF, Berlin JA, Morton SC, Olkin I, Williamson GD, Rennie $D$, et al. Meta-analysis of observational studies in epidemiology: a proposal for reporting. JAMA 2000;283(15):20082012.

25. Moher D, Liberati A, Tetzlaff J, Altman DG; PRISMA Group. Preferred reporting items for systematic reviews and meta-analyses: the PRISMA statement. BMJ 2009;339:b2535.

26. Fishman A. The effects of parity, breastfeeding, and infertility treatment on the risk of hereditary breast and ovarian cancer: a review. Int J Gynecol Cancer 2010;20(11 Suppl 2):S31-S33.

27. Wells GA, Shea B, O'Connell D, Peterson J, Welch V, Losos M, et al. The Newcastle-Ottawa Scale (NOS) for assessing the quality of nonrandomised studies in meta-analyses [cited 2016 Oct 20]. Available from: http://www.ohri.ca/programs/clinical_ epidemiology/oxford.asp.

28. Schlesselman JJ, Stolley PD. Case-control studies: design, conduct, analysis. New York: Oxford University Press; 1982, p. 3334.

29. Greenland S. Quantitative methods in the review of epidemiologic literature. Epidemiol Rev 1987;9:1-30.

30. Fleiss JL, Gross AJ. Meta-analysis in epidemiology, with special reference to studies of the association between exposure to environmental tobacco smoke and lung cancer: a critique. J Clin Epidemiol 1991;44(2):127-139.

31. Higgins JP, Thompson SG. Quantifying heterogeneity in a meta-analysis. Stat Med 2002;21(11):1539-1558.

32. Godos J, Bella F, Torrisi A, Sciacca S, Galvano F, Grosso G. Dietary patterns and risk of colorectal adenoma: a systematic review and meta-analysis of observational studies. J Hum Nutr Diet 2016. doi: https://doi.org/10.1111/jhn.12395.

33. Egger M, Davey Smith G, Schneider M, Minder C. Bias in metaanalysis detected by a simple, graphical test. BMJ 1997;315 (7109):629-634.

34. Berlin JA, Longnecker MP, Greenland S. Meta-analysis of epidemiologic dose-response data. Epidemiology 1993;4(3):218- 
228.

35. Konishi I. Gonadotropins and ovarian carcinogenesis: a new era of basic research and its clinical implications. Int J Gynecol Cancer 2006;16(1):16-22.

36. Bu SZ, Yin DL, Ren XH, Jiang LZ, Wu ZJ, Gao QR, et al. Proges- terone induces apoptosis and up-regulation of p53 expression in human ovarian carcinoma cell lines. Cancer 1997;79 (10):1944-1950.

37. McNeilly AS. Lactational control of reproduction. Reprod Fertil Dev 2001;13(7-8):583-590. 


\section{Journal of}

Preventive Medicine \& Public Health

Supplemental Table 1. Details of studies on parity and ovarian cancer risk

\begin{tabular}{|c|c|c|c|c|c|c|c|c|c|c|}
\hline $\begin{array}{l}\text { Author (year } \\
\text { of publica- } \\
\text { tion) [Ref] }\end{array}$ & Country & Age (y) & $\begin{array}{l}\text { Study } \\
\text { period }\end{array}$ & $\begin{array}{l}\text { No. of } \\
\text { cases }\end{array}$ & $\begin{array}{l}\text { No. of } \\
\text { controls } \\
\text { (cohort') }\end{array}$ & Outcome & Parity & RR/OR (95\% CI) & $\begin{array}{l}\text { Study } \\
\text { qual- } \\
\text { ity }^{2}\end{array}$ & Comments \\
\hline \multicolumn{11}{|l|}{ Cohort study } \\
\hline $\begin{array}{l}\text { Kumle et al. } \\
2004 \text { [A02] }\end{array}$ & $\begin{array}{l}\text { Norway/ } \\
\text { Sweden }\end{array}$ & $30-49$ & $1991-2000$ & 214 & (103 551) & EOC & $\begin{array}{l}\text { Nulliparous } \\
1 \\
2 \\
\geq 3\end{array}$ & $\begin{array}{l}1.0{\text { (reference })^{3}} \\
0.7(0.4,1.1) 3 \\
0.6(0.4,0.9) 3 \\
0.5(0.4,0.8) 3\end{array}$ & 8 & $\begin{array}{l}\text { The Norwegian-Swedish Women's Lifestyle } \\
\text { and Health cohort } \\
\text { Study quality: [Selection: 3, Comparability: 2, } \\
\text { Outcome: } 3 \text { ] } \\
\text { Adjusted for age }\end{array}$ \\
\hline $\begin{array}{l}\text { Tsilidis et al. } \\
2011 \text { [A04] }\end{array}$ & $\begin{array}{l}10 \\
\text { European } \\
\text { countries }\end{array}$ & 50.45 & 1992-2006 & 878 & (327 396) & EOC & $\begin{array}{l}\text { Nulliparous } \\
1 \\
2 \\
3 \\
\geq 4\end{array}$ & $\begin{array}{l}1.00 \text { (reference) } \\
0.80(0.63,1.02) \\
0.74(0.61,0.91) \\
0.64(0.50,0.81) \\
0.62(0.46,0.93)\end{array}$ & 8 & $\begin{array}{l}\text { The European Prospective Investigation into } \\
\text { Cancer and Nutrition cohort } \\
\text { Study quality: [Selection: 4, Comparability: } 2 \text {, } \\
\text { Outcome: 2] } \\
\text { Adjusted for age and oral contraceptive use }\end{array}$ \\
\hline $\begin{array}{l}\text { Weiderpass et } \\
\text { al. } 2012 \text { [A05] }\end{array}$ & Japan & $40-69$ & 1990-2008 & 86 & (45 748) & EOC & $\begin{array}{l}\text { Nulliparous } \\
1 \\
2 \\
3 \\
>3\end{array}$ & $\begin{array}{l}1.0(\text { reference })^{3} \\
1.5(0.5,4.5)^{3} \\
0.8(0.3,2.1)^{3} \\
0.6(0.2,1.8)^{3} \\
0.6(0.2,1.8)^{3}\end{array}$ & 8 & $\begin{array}{l}\text { The Japan Public Health Center-Based } \\
\text { Prospective Study cohort } \\
\text { Study quality: [Selection: 4, Comparability: 2, } \\
\text { Outcome: 2] } \\
\text { Adjusted for age and study area, age at } \\
\text { menarche, age at first birth, use of } \\
\text { exogenous hormones, menopausal status, } \\
\text { height, body mass index, smoking status, } \\
\text { physical activity, sleep duration, family } \\
\text { history of cancer }\end{array}$ \\
\hline \multicolumn{11}{|c|}{ Case-control study } \\
\hline $\begin{array}{l}\text { Booth et al. } \\
1989 \text { [A07] }\end{array}$ & UK & $\begin{array}{l}(52.4 / \\
51.4)^{5}\end{array}$ & 1978-1983 & 235 & 451 & EOC & $\begin{array}{l}\text { Nulliparous } \\
1 \\
2 \\
3 \\
4 \\
\geq 5\end{array}$ & $\begin{array}{l}1.0 \text { (reference) }^{3} \\
0.7(0.4,1.2)^{3} \\
0.6(0.4,1.0)^{3} \\
0.6(0.3,1.0)^{3} \\
0.5(0.2,1.0)^{3} \\
0.3(0.1,0.7)^{3}\end{array}$ & 6 & $\begin{array}{l}\text { Unmatched } \\
\text { Study quality: [Selection: 3, Comparability: 2, } \\
\text { Outcome: 1] } \\
\text { Adjusted for age, social class }\end{array}$ \\
\hline $\begin{array}{l}\text { Hartge et al. } \\
1989 \text { [A08] }\end{array}$ & USA & $20-79$ & 1978-1981 & 296 & 343 & EOC & $\begin{array}{l}\text { Nulliparous } \\
1 \\
2 \\
3 \\
\geq 4\end{array}$ & $\begin{array}{l}1.0(\text { reference })^{3} \\
1.0(0.6,1.7)^{3} \\
0.8(0.5,1.3)^{3} \\
0.7(0.4,1.2)^{3} \\
0.6(0.4,1.1)^{3}\end{array}$ & 7 & $\begin{array}{l}\text { Matched for hospital, age, race } \\
\text { Study quality: [Selection: 3, Comparability: } 2 \text {, } \\
\text { Outcome: 2] } \\
\text { Adjusted for age, race }\end{array}$ \\
\hline
\end{tabular}

(Continued to the next page) 
Supplemental Table 1. Continued from the previous page

\begin{tabular}{|c|c|c|c|c|c|c|c|c|c|c|}
\hline $\begin{array}{l}\text { Author (year } \\
\text { of publica- } \\
\text { tion) [Ref] }\end{array}$ & Country & Age (y) & $\begin{array}{l}\text { Study } \\
\text { period }\end{array}$ & $\begin{array}{l}\text { No. of } \\
\text { cases }\end{array}$ & $\begin{array}{c}\text { No. of } \\
\text { controls } \\
\text { (cohort') }\end{array}$ & Outcome & Parity & RR/OR (95\% Cl) & $\begin{array}{l}\text { Study } \\
\text { qual- } \\
\text { ity }^{2}\end{array}$ & Comments \\
\hline $\begin{array}{l}\text { Gwinn et al. } \\
1990 \text { [A09] }\end{array}$ & UK & $20-54$ & 1980-1982 & 436 & 3833 & EOC & $\begin{array}{l}\text { Nulliparous } \\
1 \\
2 \\
3 \\
4 \\
\geq 5\end{array}$ & $\begin{array}{l}1.00(\text { reference) } \\
0.66(0.47,0.93)^{4} \\
0.52(0.39,0.69)^{4} \\
0.45(0.34,0.62)^{4} \\
0.28(0.22,0.48)^{4} \\
0.24(0.19,0.37)^{4}\end{array}$ & 7 & $\begin{array}{l}\text { Unmatched } \\
\text { Study quality: [Selection: 4, Comparability: } 1 \text {, } \\
\text { Outcome: 2] } \\
\text { Crude OR }\end{array}$ \\
\hline $\begin{array}{l}\text { Tavani et al. } \\
1993 \text { [A11] }\end{array}$ & Italy & $18-45$ & 1983-1992 & 194 & 710 & EOC & $\begin{array}{l}\text { Nulliparous } \\
1 \\
2 \\
\geq 3\end{array}$ & $\begin{array}{l}1.00 \text { (reference) } \\
0.9(0.6,1.4)^{3} \\
1.0(0.6,1.7)^{3} \\
1.1(0.6,2.0)^{3}\end{array}$ & 7 & $\begin{array}{l}\text { Study quality: [Selection: 3, Comparability: } 2 \text {, } \\
\text { Outcome: 2] } \\
\text { Adjusted for age, education, family history, } \\
\text { number of births, number of abortions }\end{array}$ \\
\hline $\begin{array}{l}\text { Risch et al. } \\
1994 \text { [A13] }\end{array}$ & Canada & $35-79$ & 1989-1992 & 450 & 564 & EOC & $\begin{array}{l}\text { Nulliparous } \\
1 \\
2 \\
3 \\
4 \\
\geq 5\end{array}$ & $\begin{array}{l}1.00 \text { (reference) } \\
0.64(0.41,1.01) \\
0.37(0.25,0.56) \\
0.40(0.26,0.61) \\
0.27(0.16,0.46) \\
0.23(0.13,0.42)\end{array}$ & 8 & $\begin{array}{l}\text { Matched for age } \\
\text { Study quality: [Selection: 4, Comparability: } 2 \text {, } \\
\text { Outcome: 2] } \\
\text { Adjusted for age, oral contraceptive use }\end{array}$ \\
\hline $\begin{array}{r}\text { Greggi et al. } \\
2000 \text { [A16] }\end{array}$ & Italy & $13-80$ & 1988-1998 & 440 & 868 & EOC & $\begin{array}{l}\text { Nulliparous } \\
1 \\
2 \\
\geq 3\end{array}$ & $\begin{array}{l}1.0(\text { reference })^{3} \\
0.8(0.5,1.3)^{3} \\
0.9(0.6,1.4)^{3} \\
0.7(0.5,1.2)^{3}\end{array}$ & 7 & $\begin{array}{l}\text { Controls were identified in similar strata } \\
\text { of age among women admitted to the } \\
\text { same hospital } \\
\text { Study quality: [Selection: } 3 \text {, } \\
\text { Comparability: 2, Outcome: 3] } \\
\text { Adjusted for age, education, parity, oral } \\
\text { contraceptive use, family history of ovarian } \\
\text { cancer }\end{array}$ \\
\hline $\begin{array}{l}\text { Akhmedkhanov } \\
\text { et al. } 2001 \\
\text { [A17] }\end{array}$ & USA & $31-70$ & 1985-1996 & 68 & 680 & EOC & $\begin{array}{l}\text { Nulliparous } \\
1 \\
2 \\
\geq 3\end{array}$ & $\begin{array}{l}1.00 \text { (reference) } \\
0.58(0.27,1.25) \\
0.53(0.27,1.01) \\
0.45(0.22,0.92)\end{array}$ & 7 & $\begin{array}{l}\text { Matched for age, menopausal status, } \\
\text { date of enrollment, date of response } \\
\text { Study quality: [Selection: } 3 \text {, } \\
\text { Comparability: 2, Outcome: 1] } \\
\text { Adjusted for age at menarche, oral } \\
\text { contraceptive use, first degree family his- } \\
\text { tory of breast cancer before } 50\end{array}$ \\
\hline
\end{tabular}


Supplemental Table 1. Continued from the previous page

\begin{tabular}{|c|c|c|c|c|c|c|c|c|c|c|}
\hline $\begin{array}{l}\text { Author (year } \\
\text { of publica- } \\
\text { tion) [Ref] }\end{array}$ & Country & Age (y) & $\begin{array}{l}\text { Study } \\
\text { period }\end{array}$ & $\begin{array}{l}\text { No. of } \\
\text { cases }\end{array}$ & $\begin{array}{l}\text { No. of } \\
\text { controls } \\
\text { (cohort') }\end{array}$ & Outcome & Parity & $\mathrm{RR} / \mathrm{OR}(95 \% \mathrm{CI})$ & $\begin{array}{l}\text { Study } \\
\text { qual- } \\
\text { ity }^{2}\end{array}$ & Comments \\
\hline $\begin{array}{l}\text { Riman et al. } \\
2001 \text { [A18] }\end{array}$ & Sweden & $50-74$ & 1993-1995 & 193 & 3899 & BOT & $\begin{array}{l}\text { Nulliparous } \\
1 \\
2 \\
3 \\
4 \\
\geq 5\end{array}$ & $\begin{array}{l}1.00 \text { (reference) } \\
0.68(0.43,1.12) \\
0.53(0.34,0.83) \\
0.44(0.36,0.73) \\
0.27(0.12,0.61) \\
0.33(0.12,0.87)\end{array}$ & 9 & $\begin{array}{l}\text { Frequency matched by age } \\
\text { Study quality: [Selection: 4, } \\
\text { Comparability: 2, Outcome: } 3 \text { ] } \\
\text { Adjusted for age, body mass index, age } \\
\text { at menopause, duration of oral contra- } \\
\text { ceptive use }\end{array}$ \\
\hline $\begin{array}{l}\text { Tung et al. } \\
2003 \text { [A21] }\end{array}$ & USA. & $\geq 18$ & 1993-1999 & 558 & 607 & EOC & $\begin{array}{l}\text { Nulliparous } \\
1 \\
2 \\
>2\end{array}$ & $\begin{array}{l}1.0(\text { reference })^{3} \\
0.6(0.4,0.9)^{3} \\
0.6(0.4,0.9)^{3} \\
0.6(0.4,0.8)^{3}\end{array}$ & 7 & $\begin{array}{l}\text { Matched to cases with an approximate } \\
\text { 1:1 ratio on the basis of specific } \\
\text { ethnicity (e.g., Japanese), age (year of } \\
\text { birth } \pm 5 \text { y), and study site. } \\
\text { Study quality: [Selection: } 3 \text {, } \\
\text { Comparability: } 2 \text {, Outcome: 2] } \\
\text { Adjusted for age, ethnicity, study site, } \\
\text { education, tubal ligation, hormone } \\
\text { replacement therapy, and ovulation } \\
\text { variables }\end{array}$ \\
\hline $\begin{array}{l}\text { Rossing et al. } \\
2004 \text { [A24] }\end{array}$ & USA & $35-54$ & 1994-1998 & 378 & 1637 & EOC & $\begin{array}{l}\text { Nulliparous } \\
1 \\
2 \\
\geq 3\end{array}$ & $\begin{array}{l}1.0(\text { reference) } \\
0.7(0.5,1.0)^{3} \\
0.6(0.5,0.9)^{3} \\
0.5(0.3,0.7)^{3}\end{array}$ & 6 & $\begin{array}{l}\text { Matched for area of residence and age } \\
\text { Study quality: [Selection: } 3 \text {, } \\
\text { Comparability: } 2, \text { Outcome: 1] } \\
\text { Adjusted for age, race and study site }\end{array}$ \\
\hline $\begin{array}{c}\text { Chiaffarino et al. } \\
2005 \text { [A25] }\end{array}$ & Italy & $18-79$ & 1992-1999 & 1031 & 2411 & EOC & $\begin{array}{l}\text { Nulliparous } \\
1 \\
2 \\
3 \\
\geq 4\end{array}$ & $\begin{array}{l}1.0 \text { (reference) }^{3} \\
1.1(0.8,1.5)^{3} \\
1.0(0.8,1.3)^{3} \\
0.6(0.5,0.9)^{3} \\
0.5(0.3,0.7)^{3}\end{array}$ & 7 & $\begin{array}{l}\text { Matched for age } \\
\text { Study quality: [Selection: 3, } \\
\text { Comparability: 2, Outcome: 2] } \\
\text { Adjusted for age and study center, } \\
\text { education, oral contraceptive use and } \\
\text { family history }\end{array}$ \\
\hline
\end{tabular}


Supplemental Table 1. Continued from the previous page

\begin{tabular}{|c|c|c|c|c|c|c|c|c|c|c|}
\hline $\begin{array}{l}\text { Author (year } \\
\text { of publica- } \\
\text { tion) [Ref] }\end{array}$ & Country & Age (y) & $\begin{array}{l}\text { Study } \\
\text { period }\end{array}$ & $\begin{array}{l}\text { No. of } \\
\text { cases }\end{array}$ & $\begin{array}{l}\text { No. of } \\
\text { controls } \\
\text { (cohort') }\end{array}$ & Outcome & Parity & RR/OR (95\% Cl) & $\begin{array}{l}\text { Study } \\
\text { qual- } \\
\text { ity }^{2}\end{array}$ & Comments \\
\hline $\begin{array}{c}\text { El-Khwsky et al. } \\
2006 \text { [A26] }\end{array}$ & Egypt & $20-79$ & $2000-2003$ & 172 & 441 & EOC & $\begin{array}{l}\text { Nulliparous } \\
1 \\
2 \\
3 \\
\geq 4\end{array}$ & $\begin{array}{l}1.00 \text { (reference) } \\
0.36(0.16,0.78) \\
0.36(0.19,0.68) \\
0.52(0.27,0.97) \\
0.56(0.34,0.94)\end{array}$ & 5 & $\begin{array}{l}\text { Matched by age and address } \\
\text { Study quality: [Selection: 2, } \\
\text { Comparability: 2,Outcome: 1] } \\
\text { Crude OR }\end{array}$ \\
\hline $\begin{array}{c}\text { Huusom et al. } \\
2006 \text { [A27] }\end{array}$ & Denmark & $35-79$ & 1995-1999 & 202 & 1564 & ВОТ & $\begin{array}{l}1 \\
2 \\
3 \\
\geq 4\end{array}$ & $\begin{array}{l}1.00 \text { (reference) } \\
0.51(0.33,0.79) \\
0.41(0.23,0.72) \\
0.51(0.24,1.08)\end{array}$ & 7 & $\begin{array}{l}\text { Frequency matched in } 5 \text { y intervals } \\
\text { by using age distribution women with } \\
\text { ovarian cancer } \\
\text { Study quality: [Selection: } 4 \text {, } \\
\text { Comparability: 2,Outcome: 1] } \\
\text { Adjusted for age, age at first birth, } \\
\text { duration of oral contraceptives } \\
\text { smoking, intake of milk }\end{array}$ \\
\hline $\begin{array}{l}\text { Soegaard et al. } \\
2007 \text { [A28] }\end{array}$ & Denmark & $35-79$ & 1995-1999 & 554 & 1564 & EOC & $\begin{array}{l}1 \\
2 \\
\geq 3\end{array}$ & $\begin{array}{l}1.00 \text { (reference) } \\
0.63(0.45,0.87) \\
0.51(0.37,0.69)\end{array}$ & 7 & $\begin{array}{l}\text { Frequency-matched in } 5 \text { y intervals } \\
\text { by age using computerized civil } \\
\text { registration data } \\
\text { Study quality: [Selection: 4, } \\
\text { Comparability: } 2, \text { Outcome: 1] } \\
\text { Adjusted for age, pregnancy and } \\
\text { duration of oral contraceptive use }\end{array}$ \\
\hline $\begin{array}{l}\text { Fujita et al. } \\
2008 \text { [A29] }\end{array}$ & Japan & $\geq 30$ & 1997-2003 & 141 & 2016 & Total OC & $\begin{array}{l}\text { Nulliparous } \\
1 \\
2 \\
\geq 3\end{array}$ & $\begin{array}{l}1.00 \text { (reference) } \\
0.57(0.28,1.17) \\
0.39(0.22,0.69) \\
0.31(0.17,0.57)\end{array}$ & 7 & $\begin{array}{l}\text { Unmatched } \\
\text { Study quality: [Selection: 3, } \\
\text { Comparability: 2, Outcome: 2] } \\
\text { Adjusted for age, year of survey, referral } \\
\text { base, area of residence, smoking } \\
\text { history, history of alcohol drinking, } \\
\text { family history of index cancer, } \\
\text { occupation, age at menarche }\end{array}$ \\
\hline $\begin{array}{c}\text { Moorman et al. } \\
2008 \text { [A30] }\end{array}$ & USA & $20-74$ & 1999-2006 & 869 & 967 & $\mathrm{EOC}$ & $\begin{array}{l}\text { Nulliparous } \\
1 \\
2 \\
3 \\
>3\end{array}$ & $\begin{array}{l}1.00(\text { reference) } \\
0.66(0.46,0.90)^{4} \\
0.37(0.28,0.49)^{4} \\
0.53(0.39,0.72)^{4} \\
0.66(0.47,0.92)^{4}\end{array}$ & 7 & $\begin{array}{l}\text { Frequency matched by age and race } \\
\text { Study quality: [Selection: } 4 \text {, } \\
\text { Comparability: 2, Outcome: } 2 \text { ] } \\
\text { Crude OR }\end{array}$ \\
\hline $\begin{array}{l}\text { Kurta et al. } \\
2012 \text { [A31] }\end{array}$ & USA & $\geq 25$ & 2003-2008 & 902 & 1802 & $\mathrm{EOC}$ & $\begin{array}{l}\text { Nulliparous } \\
1 \\
2 \\
3 \\
4 \\
\geq 5\end{array}$ & $\begin{array}{l}1.00 \text { (reference) } \\
0.51(0.38,0.68) \\
0.45(0.35,0.57) \\
0.39(0.30,0.51) \\
0.32(0.23,0.45) \\
0.32(0.22,0.47)\end{array}$ & 7 & $\begin{array}{l}\text { Frequency matched by age (5 y } \\
\text { categories). Telephone area code } \\
\text { through random digit dialing } \\
\text { Study quality: [Selection: } 4 \text {, } \\
\text { Comparability: } 2 \text {, Outcome: 1] } \\
\text { Adjusted for age, race, education }\end{array}$ \\
\hline $\begin{array}{l}\text { Le et al. } \\
2012 \text { [A32] }\end{array}$ & Vietnam & $40-59$ & 2001-2006 & 262 & 755 & Total OC & $\begin{array}{l}\text { Nulliparous } \\
1 \\
2 \\
3 \\
4 \\
\geq 5\end{array}$ & $\begin{array}{l}1.0(\text { reference) } \\
0.8(0.4,1.7)^{3} \\
0.5(0.2,0.9)^{3} \\
0.4(0.2,0.7)^{3} \\
0.2(0.1,0.3)^{3} \\
0.2(0.1,0.4)^{3}\end{array}$ & 7 & $\begin{array}{l}\text { Matched for age } \\
\text { Study quality: [Selection: 4, } \\
\text { Comparability: 2, Outcome: 1] } \\
\text { Adjusted for age, education level, body } \\
\text { mass index, menopausal status, age at } \\
\text { menarche, oral contraceptive use }\end{array}$ \\
\hline
\end{tabular}

EOC, epithelial ovarian cancer; OC, ovarian cancer; BOT, borderline ovarian tumor; OR, odds ratio; RR, relative risk; Cl, confidence interval.

${ }^{1}$ Number of total cohort.

${ }^{2}$ Study quality was judged based on the Newcastle-Ottawa Scale (range, 1-9 points).

${ }^{3}$ Values is listed to one decimal point in the original data.

${ }^{4}$ Mantel-Haenszel crude estimates of the ORs/RRs and corresponding 95\% Cls were calculated when the ORs/RRs were not presented.

${ }^{5}$ Mean age.

A01. Hankinson SE, Colditz GA, Hunter DJ, Willett WC, Stampfer MJ, Rosner B, et al. A prospective study of reproductive factors and risk of epithelial ovarian cancer. Cancer 1995;76(2):284-290.

A02. Kumle M, Weiderpass E, Braaten T, Adami HO, Lund E; Norwegian-Swedish Women's Lifestyle and Health Cohort Study. Risk for invasive and borderline epithelial ovarian neoplasias following use of hormonal contraceptives: the Norwegian-Swedish Women's Lifestyle and Health Cohort Study. Br J Cancer 2004;90(7):1386-1391.

A03. Lacey JV Jr, Leitzmann M, Brinton LA, Lubin JH, Sherman ME, Schatzkin A, et al. Weight, height, and body mass index and risk for ovarian cancer in a co- 


\section{Journal of

hort study. Ann Epidemiol 2006;16(12):869-876.

A04. Tsilidis KK, Allen NE, Key TJ, Dossus L, Lukanova A, Bakken K, et al. Oral contraceptive use and reproductive factors and risk of ovarian cancer in the European Prospective Investigation into Cancer and Nutrition. Br J Cancer 2011;105(9):1436-1442.

A05. Weiderpass E, Sandin S, Inoue M, Shimazu T, Iwasaki M, Sasazuki S, et al. Risk factors for epithelial ovarian cancer in Japan - results from the Japan Public Health Center-based Prospective Study cohort. Int J Oncol 2012;40(1):21-30.

A06. Yang HP, Trabert B, Murphy MA, Sherman ME, Sampson JN, Brinton LA, et al. Ovarian cancer risk factors by histologic subtypes in the NIH-AARP Diet and Health Study. Int J Cancer 2012;131(4):938-948.

A07. Booth M, Beral V, Smith P. Risk factors for ovarian cancer: a case-control study. Br J Cancer 1989;60(4):592-598.

A08. Hartge P, Schiffman MH, Hoover R, McGowan L, Lesher L, Norris HJ. A case-control study of epithelial ovarian cancer. Am J Obstet Gynecol 1989;161(1):10-16.

A09. Gwinn ML, Lee NC, Rhodes PH, Layde PM, Rubin GL. Pregnancy, breast feeding, and oral contraceptives and the risk of epithelial ovarian cancer. J Clin Epidemiol 1990;43(6):559-568.

A10. Chen Y, Wu PC, Lang JH, Ge WJ, Hartge P, Brinton LA. Risk factors for epithelial ovarian cancer in Beijing, China. Int J Epidemiol 1992;21(1):23-29.

A11. Tavani A, Negri E, Franceschi S, Parazzini F, La Vecchia C. Risk factors for epithelial ovarian cancer in women under age 45. Eur J Cancer 1993;29A(9):12971301.

A12. Adami H0, Hsieh CC, Lambe M, Trichopoulos D, Leon D, Persson I, et al. Parity, age at first childbirth, and risk of ovarian cancer. Lancet 1994;344(8932): 1250-1254

A13. Risch HA, Marrett LD, Howe GR. Parity, contraception, infertility, and the risk of epithelial ovarian cancer. Am J Epidemiol 1994;140(7):585-597.

A14. Purdie D, Green A, Bain C, Siskind V, Ward B, Hacker N, et al. Reproductive and other factors and risk of epithelial ovarian cancer: an Australian casecontrol study. Survey of Women's Health Study Group. Int J Cancer 1995;62(6):678-684.

A15. Ness RB, Grisso JA, Klapper J, Schlesselman JJ, Silberzweig S, Vergona R, et al. Risk of ovarian cancer in relation to estrogen and progestin dose and use characteristics of oral contraceptives. Am J Epidemiol 2000;152(3):233-241.

A16. Greggi S, Parazzini F, Paratore MP, Chatenoud L, Legge F, Mancuso S, et al. Risk factors for ovarian cancer in central Italy. Gynecol Oncol 2000;79(1):50-54.

A17. Akhmedkhanov A, Toniolo P, Zeleniuch-Jacquotte A, Kato I, Koenig KL, Shore RE. Aspirin and epithelial ovarian cancer. Prev Med 2001;33(6):682-687.

A18. Riman T, Dickman PW, Nilsson S, Correia N, Nordlinder H, Magnusson CM, et al. Risk factors for epithelial borderline ovarian tumors: results of a Swedish case-control study. Gynecol Oncol 2001;83(3):575-585.

A19. Titus-Ernstoff L, Perez K, Cramer DW, Harlow BL, Baron JA, Greenberg ER. Menstrual and reproductive factors in relation to ovarian cancer risk. Br J Cancer 2001:84(5):714-721.

A20. Riman T, Dickman PW, Nilsson S, Correia N, Nordlinder H, Magnusson CM, et al. Risk factors for invasive epithelial ovarian cancer: results from a Swedish case-control study. Am J Epidemiol 2002;156(4):363-373.

A21. Tung KH, Goodman MT, Wu AH, McDuffie K, Wilkens LR, Kolonel LN, et al. Reproductive factors and epithelial ovarian cancer risk by histologic type: a multiethnic case-control study. Am J Epidemiol 2003;158(7):629-638.

A22. Mills PK, Riordan DG, Cress RD. Epithelial ovarian cancer risk by invasiveness and cell type in the Central Valley of California. Gynecol Oncol 2004;95(1): 215-225.

A23. Pike MC, Pearce CL, Peters R, Cozen W, Wan P, Wu AH. Hormonal factors and the risk of invasive ovarian cancer: a population-based case-control study. Fertil Steril 2004;82(1):186-195.

A24. Rossing MA, Tang MT, Flagg EW, Weiss LK, Wicklund KG. A case-control study of ovarian cancer in relation to infertility and the use of ovulation-inducing drugs. Am J Epidemiol 2004;160(11):1070-1078.

A25. Chiaffarino F, Pelucchi C, Negri E, Parazzini F, Franceschi S, Talamini R, et al. Breastfeeding and the risk of epithelial ovarian cancer in an Italian population. Gynecol Oncol 2005;98(2):304-308.

A26. El-Khwsky FS, Maghraby HK, Rostom YA, Abd El-Rahman AH. Multivariate analysis of reproductive risk factors for ovarian cancer in Alexandria, Egypt. J Egypt Natl Canc Inst 2006;18(1):30-34.

A27. Huusom LD, Frederiksen K, Høgdall EV, Glud E, Christensen L, Høgdall CK, et al. Association of reproductive factors, oral contraceptive use and selected lifestyle factors with the risk of ovarian borderline tumors: a Danish case-control study. Cancer Causes Control 2006;17(6):821-829.

A28. Soegaard M, Jensen A, Høgdall E, Christensen L, Høgdall C, Blaakaer J, et al. Different risk factor profiles for mucinous and nonmucinous ovarian cancer: results from the Danish MALOVA study. Cancer Epidemiol Biomarkers Prev 2007;16(6):1160-1166.

A29. Fujita M, Tase T, Kakugawa Y, Hoshi S, Nishino Y, Nagase S, et al. Smoking, earlier menarche and low parity as independent risk factors for gynecologic cancers in Japanese: a case-control study. Tohoku J Exp Med 2008;216(4):297-307.

A30. Moorman PG, Calingaert B, Palmieri RT, Iversen ES, Bentley RC, Halabi S, et al. Hormonal risk factors for ovarian cancer in premenopausal and postmenopausal women. Am J Epidemiol 2008;167(9):1059-1069.

A31. Kurta ML, Moysich KB, Weissfeld JL, Youk AO, Bunker CH, Edwards RP, et al. Use of fertility drugs and risk of ovarian cancer: results from a U.S.-based case-control study. Cancer Epidemiol Biomarkers Prev 2012;21(8):1282-1292.

A32. Le DC, Kubo T, Fujino Y, Sokal DC, Vach TH, Pham TM, et al. Reproductive factors in relation to ovarian cancer: a case-control study in Northern Vietnam. Contraception 2012;86(5):494-499. 
Supplemental Table 2. Details of studies on breastfeeding and ovarian cancer risk

\begin{tabular}{|c|c|c|c|c|c|c|c|c|c|c|}
\hline $\begin{array}{l}\text { Author (year } \\
\text { of publica- } \\
\text { tion) [Ref] }\end{array}$ & Country & Age (y) & $\begin{array}{l}\text { Study } \\
\text { period }\end{array}$ & $\begin{array}{l}\text { No. of } \\
\text { cases }\end{array}$ & $\begin{array}{l}\text { No. of } \\
\text { controls } \\
\left(\text { cohort }^{1}\right)\end{array}$ & $\begin{array}{l}\text { Out- } \\
\text { come }\end{array}$ & $\begin{array}{l}\text { Breast- } \\
\text { feeding } \\
\text { (mo) }\end{array}$ & RR $(95 \%$ CI) & $\begin{array}{l}\text { Study } \\
\text { qual- } \\
\text { ity }^{2}\end{array}$ & Comment \\
\hline \multicolumn{11}{|l|}{ Cohort study } \\
\hline $\begin{array}{c}\text { Danforth et al. } \\
2007 \text { [B01] }\end{array}$ & USA & $\begin{array}{l}30-55 \\
/ 20-42\end{array}$ & $\begin{array}{l}\text { 1986-2002 } \\
/ 1993-2003\end{array}$ & 391 & (149 693) & EOC & $\begin{array}{l}\text { Never } \\
1-6 \\
7-11 \\
12-17 \\
18+\end{array}$ & $\begin{array}{l}1.00 \text { (reference) } \\
0.96(0.76,1.21) \\
0.76(0.52,1.11) \\
0.82(0.54,1.24) \\
0.66(0.46,0.96)\end{array}$ & 8 & $\begin{array}{l}\text { The Nurses' Health Study and Nurses' } \\
\text { Health Study II } \\
\text { Study quality: [Selection: 2, } \\
\text { Comparability: 2, Outcome: 3] } \\
\text { Adjusted for age, parity, duration of oral } \\
\text { contraceptive use, tubal ligation, age } \\
\text { at menarche }\end{array}$ \\
\hline $\begin{array}{l}\text { Tsilidis et al. } \\
2011 \text { [B02] }\end{array}$ & $\begin{array}{l}10 \\
\text { European } \\
\text { countries }\end{array}$ & $50.4^{5}$ & 1992-2006 & 878 & (327 396) & EOC & $\begin{array}{l}\leq 1 \\
2-6 \\
7-12 \\
>3\end{array}$ & $\begin{array}{l}1.00 \text { (reference) } \\
0.84(0.68,1.03) \\
0.91(0.72,1.14) \\
0.66(0.46,0.96)\end{array}$ & 8 & $\begin{array}{l}\text { The European Prospective Investigation } \\
\text { into Cancer and Nutrition cohort } \\
\text { Study quality: [Selection: 4, } \\
\text { Comparability: 2, Outcome: 2] } \\
\text { Adjusted for age and oral contraceptive } \\
\text { use }\end{array}$ \\
\hline \multicolumn{11}{|c|}{ Case-control study } \\
\hline $\begin{array}{l}\text { Booth et al. } \\
1989 \text { [B03] }\end{array}$ & UK & $(52.4 / 51.4)^{5}$ & 1978-1983 & 235 & 451 & EOC & $\begin{array}{l}\text { Never } \\
\leq 6 \\
7-12 \\
13-18 \\
19-24 \\
\geq 25\end{array}$ & $\begin{array}{l}1.0 \text { (reference) }^{3} \\
0.3(0.8,2.2)^{3} \\
0.9(0.5,1.6)^{3} \\
1.2(0.5,2.5)^{3} \\
2.1(0.7,6.7)^{3} \\
3.4(1.1,10.8)^{3}\end{array}$ & 6 & $\begin{array}{l}\text { Unmatched } \\
\text { Study quality: [Selection: } 3 \text {, } \\
\text { Comparability: 2, Outcome: 1] } \\
\text { Adjusted for age, number of live births }\end{array}$ \\
\hline $\begin{array}{l}\text { Gwinn et al. } \\
1990 \text { [B04] }\end{array}$ & UK & $20-54$ & 1980-1982 & 436 & 3833 & EOC & $\begin{array}{l}\text { Never } \\
1-2 \\
3-5 \\
6-11 \\
12-23 \\
\geq 24\end{array}$ & $\begin{array}{l}1.0 \\
0.6^{4} \\
0.8^{4} \\
0.8^{4} \\
0.7^{4} \\
0.3^{4}\end{array}$ & 7 & $\begin{array}{l}\text { Unmatched } \\
\text { Study quality: [Selection: 4, } \\
\text { Comparability: 1, Outcome: 2] } \\
\text { Adjusted for pregnancy, oral } \\
\text { contraceptive use. age }\end{array}$ \\
\hline $\begin{array}{r}\text { Siskind et al. } \\
1997 \text { [B05] }\end{array}$ & Australia & $18-79$ & 1990-1993 & 824 & 855 & $\mathrm{EOC}$ & $\begin{array}{l}\text { Never } \\
1-6 \\
7-12 \\
13-24 \\
25-36 \\
>36\end{array}$ & $\begin{array}{l}1.00 \text { (reference) } \\
0.89(0.65,1.21) \\
0.68(0.49,0.94) \\
0.84(0.59,1.20) \\
0.69(0.38,1.27) \\
0.77(0.34,1.75)\end{array}$ & 7 & $\begin{array}{l}\text { Matched for age and residence } \\
\text { Study quality: [Selection: } 4, \\
\text { Comparability: 2, Outcome: 1] } \\
\text { Adjusted for number of live born } \\
\text { children, age, use of oral contracep- } \\
\text { tives, education, smoking history }\end{array}$ \\
\hline $\begin{array}{l}\text { Hirose et al. } \\
1999 \text { [B06] }\end{array}$ & Japan & $(51.8 / 48.5)^{5}$ & 1998-1995 & 95 & 25488 & EOC & $\begin{array}{l}\text { Never } \\
1-5 \\
6-11 \\
\geq 12\end{array}$ & $\begin{array}{l}1.00 \text { (reference) } \\
0.89(0.39,2.03) \\
1.18(0.54,2.60) \\
0.70(0.31,1.55)\end{array}$ & 5 & $\begin{array}{l}\text { Unmatched } \\
\text { Study quality: [Selection: } 4 \\
\text { Comparability: 2, Outcome: 1] } \\
\text { Adjusted for age, body mass index }\end{array}$ \\
\hline $\begin{array}{l}\text { Ness et al. } \\
2000 \text { [B07] }\end{array}$ & USA & $20-69$ & 1994-1998 & 767 & 1367 & $\mathrm{EOC}$ & $\begin{array}{l}\text { Never } \\
1-5 \\
6-11 \\
12-23 \\
\geq 24\end{array}$ & $\begin{array}{l}1.0 \text { (reference) }^{3} \\
0.9(0.7,1.2)^{3} \\
0.9(0.6,1.3)^{3} \\
0.7(0.5,1.1)^{3} \\
0.6(0.4,1.0)^{3}\end{array}$ & 7 & $\begin{array}{l}\text { Study quality: [Selection: } 4 \\
\text { Comparability: 2, Outcome: 1] } \\
\text { Adjusted for age, number of pregnancies, } \\
\text { family history of ovarian cancer, race, } \\
\text { oral contraceptive use, tubal ligation, } \\
\text { hysterectomy and breast-feeding }\end{array}$ \\
\hline $\begin{array}{l}\text { Riman et al. } \\
2001 \text { [B08] }\end{array}$ & Sweden & $50-74$ & 1993-1995 & 193 & 3899 & ВОТ & $\begin{array}{l}\text { Never } \\
1-5 \\
6-11 \\
\geq 12\end{array}$ & $\begin{array}{l}1.00 \text { (reference) } \\
0.72(0.38,1.36) \\
0.52(0.28,1.00) \\
0.47(0.24,0.94)\end{array}$ & 9 & $\begin{array}{l}\text { Frequency matched by age } \\
\text { Study quality: [Selection: } 4 \text {, } \\
\text { Comparability: } 2 \text {, Outcome: } 3 \text { ] } \\
\text { Adjusted for age, body mass index, age } \\
\text { at menopause, duration of oral contra- } \\
\text { ceptive use }\end{array}$ \\
\hline
\end{tabular}




\section{Journal of}

Preventive Medicine \& Public Health

Supplemental Table 2. Continued from the previous page

\begin{tabular}{|c|c|c|c|c|c|c|c|c|c|c|}
\hline $\begin{array}{l}\text { Author (year } \\
\text { of publica- } \\
\text { tion) [Ref] }\end{array}$ & Country & Age (y) & $\begin{array}{l}\text { Study } \\
\text { period }\end{array}$ & $\begin{array}{l}\text { No. of } \\
\text { cases }\end{array}$ & $\begin{array}{c}\text { No. of } \\
\text { controls } \\
\text { (cohort') }\end{array}$ & $\begin{array}{c}\text { Out- } \\
\text { come }\end{array}$ & $\begin{array}{l}\text { Breast- } \\
\text { feeding } \\
(\mathrm{mo})\end{array}$ & RR $(95 \%$ CI) & $\begin{array}{l}\text { Study } \\
\text { qual- } \\
\text { ity }^{2}\end{array}$ & Comment \\
\hline $\begin{array}{l}\text { Riman et al. } \\
2002 \text { [B09] }\end{array}$ & Sweden & $50-74$ & 1993-1995 & 655 & 3899 & $\begin{array}{l}\text { Invasive } \\
\text { EOC }\end{array}$ & $\begin{array}{l}\text { Never } \\
1-5 \\
6-11 \\
\geq 12\end{array}$ & $\begin{array}{l}1.00 \text { (reference) } \\
0.99(0.64,1.52) \\
0.77(0.50,1.19) \\
0.87(0.56,1.35)\end{array}$ & 9 & $\begin{array}{l}\text { Study quality: [Selection: 4, } \\
\text { Comparability: 2, Outcome: 3] } \\
\text { Adjusted for age, body mass index, age } \\
\text { at menopause, duration of oral contra- } \\
\text { ceptive use as categorized variables, } \\
\text { any lifetime use of hormone replace- } \\
\text { ment therapy }\end{array}$ \\
\hline $\begin{array}{l}\text { Tung et al. } \\
2003 \text { [B10] }\end{array}$ & USA. & $\geq 18$ & 1993-1999 & 558 & 607 & EOC & $\begin{array}{l}\text { Never } \\
\leq 5 \\
6-12 \\
>12\end{array}$ & $\begin{array}{l}1.0(\text { reference })^{3} \\
0.6(0.4,0.7)^{3} \\
0.6(0.4,0.9)^{3} \\
0.6(0.4,0.9)^{3}\end{array}$ & 7 & $\begin{array}{l}\text { Matched to cases with an approximate } \\
1: 1 \text { ratio on the basis of specific ethnic- } \\
\text { ity (e.g., Japanese), age (year of birth } \\
\pm 5 \text { y), and study site } \\
\text { Study quality: [Selection: } 3 \text {, } \\
\text { Comparability: } 2 \text {, Outcome: } 2 \text { ] } \\
\text { Adjusted for age, ethnicity, study site, } \\
\text { education, tubal ligation, hormone } \\
\text { replacement therapy, and ovulation } \\
\text { variables }\end{array}$ \\
\hline $\begin{array}{l}\text { Mills et al. } \\
2004 \text { [B11] }\end{array}$ & USA. & $\geq 18$ & 2000-2001 & 256 & 1122 & EOC & $\begin{array}{l}\text { Never } \\
<6 \\
6-11 \\
12-23 \\
\geq 24\end{array}$ & $\begin{array}{l}1.00 \text { (reference) } \\
0.37(0.16,0.83) \\
0.42(0.20,0.90) \\
0.41(0.19,0.90) \\
0.36(0.16,0.80)\end{array}$ & 7 & $\begin{array}{l}\text { Frequency matched on age and ethnicity } \\
\text { Study quality: [Selection: 4, } \\
\text { Comparability: } 2 \text {, Outcome: 1] } \\
\text { Adjusted for age, race, ethnicity, oral } \\
\text { contraceptive use and breastfeeding }\end{array}$ \\
\hline $\begin{array}{l}\text { Rossing et al. } \\
2004 \text { [B12] }\end{array}$ & USA & $35-54$ & 1994-1998 & 378 & 1637 & EOC & $\begin{array}{l}\text { Never } \\
<6 \\
6-12 \\
\geq 12\end{array}$ & $\begin{array}{l}1.0(\text { reference })^{3} \\
0.9(0.7,1.3)^{3} \\
0.8(0.5,1.2)^{3} \\
0.5(0.3,0.7)^{3}\end{array}$ & 6 & $\begin{array}{l}\text { Matched for area of residence and age } \\
\text { Study quality: [Selection: } 3 \text {, } \\
\text { Comparability: } 2 \text {, Outcome: 1] } \\
\text { Adjusted for age, race and study site }\end{array}$ \\
\hline $\begin{array}{l}\text { Huusom et al. } \\
2006 \text { [B13] }\end{array}$ & Denmark & $35-79$ & 1995-1999 & 202 & 1564 & BOT & $\begin{array}{l}\text { Never } \\
1-5 \\
6-11 \\
12-24 \\
\geq 25\end{array}$ & $\begin{array}{l}0.97(0.50,1.86) \\
1.00 \text { (reference) } \\
0.73(0.48,1.13) \\
0.93(0.57,1.50) \\
0.32(0.11,0.95)\end{array}$ & 7 & $\begin{array}{l}\text { Frequency matched in } 5 \text { y intervals } \\
\text { by using age distribution women with } \\
\text { ovarian cancer } \\
\text { Study quality: [Selection: 4, } \\
\text { Comparability: 2,Outcome: 1] } \\
\text { Adjusted for age, age at first birth, } \\
\text { duration of oral contraceptives } \\
\text { smoking, intake of milk }\end{array}$ \\
\hline $\begin{array}{l}\text { Moorman et } \\
\text { al. } 2008 \text { [B14] }\end{array}$ & USA & $20-74$ & 1999-2006 & 869 & 967 & EOC & $\begin{array}{l}\text { Never } \\
<6 \\
6-12 \\
>12\end{array}$ & $\begin{array}{l}1.00 \text { (reference) } \\
0.78(0.68,1.12) \\
0.74(0.43,0.80) \\
0.92(0.51,1.40)\end{array}$ & 7 & $\begin{array}{l}\text { Frequency matched by age and race } \\
\text { Study quality: [Selection: 4, } \\
\text { Comparability: 2, Outcome: 2] } \\
\text { Crude OR }\end{array}$ \\
\hline $\begin{array}{l}\text { Kurta et al. } \\
2012 \text { [B15] }\end{array}$ & USA & $\geq 25$ & 2003-2008 & 902 & 1802 & EOC & $\begin{array}{l}\text { Never } \\
<6 \\
6-11 \\
\geq 12\end{array}$ & $\begin{array}{l}1.00 \text { (reference) } \\
0.60(0.47,0.76) \\
0.54(0.40,0.72) \\
0.46(0.36,0.59)\end{array}$ & 7 & $\begin{array}{l}\text { Frequency matched by age (5 y } \\
\text { categories) } \\
\text { Telephone area code through random } \\
\text { digit dialing } \\
\text { Study quality: [Selection: } 4 \text {, } \\
\text { Comparability: } 2 \text {, Outcome: } 1 \text { ] } \\
\text { Adjusted for age, race, education }\end{array}$ \\
\hline
\end{tabular}

EOC, epithelial ovarian cancer; OC, ovarian cancer; BOT, borderline ovarian tumor; OR, odds ratio; $\mathrm{RR}$, relative risk; Cl, confidence interval.

${ }^{1}$ Number of total cohort.

${ }^{2}$ Study quality was judged based on the Newcastle-Ottawa Scale (range, 1-9 points).

${ }^{3}$ Values is listed to 1 decimal point in the original data.

${ }^{4}$ The $95 \% \mathrm{Cl}$ was not presented in the original article.

${ }^{5}$ Mean age.

B01. Danforth KN, Tworoger SS, Hecht JL, Rosner BA, Colditz GA, Hankinson SE. Breastfeeding and risk of ovarian cancer in two prospective cohorts. Cancer Causes Control 2007;18(5):517-523.

B02. Tsilidis KK, Allen NE, Key TJ, Dossus L, Lukanova A, Bakken K, et al. Oral contraceptive use and reproductive factors and risk of ovarian cancer in the European Prospective Investigation into Cancer and Nutrition. Br J Cancer 2011;105(9):1436-1442.

B03. Booth M, Beral V, Smith P. Risk factors for ovarian cancer: a case-control study. Br J Cancer 1989;60(4):592-598.

B04. Gwinn ML, Lee NC, Rhodes PH, Layde PM, Rubin GL. Pregnancy, breast feeding, and oral contraceptives and the risk of epithelial ovarian cancer. J Clin Epi- 
demiol 1990;43(6):559-568

B05. Siskind V, Green A, Bain C, Purdie D. Breastfeeding, menopause, and epithelial ovarian cancer. Epidemiology 1997;8(2):188-191.

B06. Hirose K, Tajima K, Hamajima N, Kuroishi T, Kuzuya K, Miura S, et al. Comparative case-referent study of risk factors among hormone-related female cancers in Japan. Jpn J Cancer Res 1999;90(3):255-261.

B07. Ness RB, Grisso JA, Klapper J, Schlesselman JJ, Silberzweig S, Vergona R, et al. Risk of ovarian cancer in relation to estrogen and progestin dose and use characteristics of oral contraceptives. Am J Epidemiol 2000;152(3):233-241.

B08. Riman T, Dickman PW, Nilsson S, Correia N, Nordlinder H, Magnusson CM, et al. Risk factors for epithelial borderline ovarian tumors: results of a Swedish case-control study. Gynecol Oncol 2001;83(3):575-585.

B09. Riman T, Dickman PW, Nilsson S, Correia N, Nordlinder H, Magnusson CM, et al. Risk factors for invasive epithelial ovarian cancer: results from a Swedish case-control study. Am J Epidemiol 2002;156(4):363-373.

B10. Tung KH, Goodman MT, Wu AH, McDuffie K, Wilkens LR, Kolonel LN, et al. Reproductive factors and epithelial ovarian cancer risk by histologic type: a multiethnic case-control study. Am J Epidemiol 2003;158(7):629-638.

B11. Mills PK, Riordan DG, Cress RD. Epithelial ovarian cancer risk by invasiveness and cell type in the Central Valley of California. Gynecol Oncol 2004;95(1): 215-225.

B12. Rossing MA, Tang MT, Flagg EW, Weiss LK, Wicklund KG. A case-control study of ovarian cancer in relation to infertility and the use of ovulation-inducing drugs. Am J Epidemiol 2004;160(11):1070-1078.

B13. Huusom LD, Frederiksen K, Høgdall EV, Glud E, Christensen L, Høgdall CK, et al. Association of reproductive factors, oral contraceptive use and selected lifestyle factors with the risk of ovarian borderline tumors: a Danish case-control study. Cancer Causes Control 2006;17(6):821-829.

B14. Moorman PG, Calingaert B, Palmieri RT, Iversen ES, Bentley RC, Halabi S, et al. Hormonal risk factors for ovarian cancer in premenopausal and postmenopausal women. Am J Epidemiol 2008;167(9):1059-1069.

B15. Kurta ML, Moysich KB, Weissfeld JL, Youk AO, Bunker CH, Edwards RP, et al. Use of fertility drugs and risk of ovarian cancer: results from a U.S.-based case-control study. Cancer Epidemiol Biomarkers Prev 2012;21(8):1282-1292. 